\title{
Influence of Salicylic Acid, Growth Regulators and Organics on Germination and Graft Take on Mango (Mangifera indica L.) Stones
}

\author{
A. Vidya ${ }^{1}$, G.S.K. Swamy ${ }^{2}$ and R. Praveenakumar ${ }^{{ }^{*}}$ \\ ${ }^{1}$ Department of Horticulture, GKVK, University of Agricultural Sciences, \\ Bangalore-560065, India \\ ${ }^{2}$ Department of Fruit Science, College of Horticulture, Arabhavi-591306, India
}

\section{Keywords \\ GA3, Germination index, Silicylic acid, Graft success, Graft survivability. \\ Article Info \\ Accepted: \\ 08 July 2018 \\ Available Online: \\ 10 August 2018}

A B S T R A C T

The better germination per cent of mango (Mangifera indica L.) stones is the criterion and strong base for successful grafts hence to enhance the germination, growth and graft parameters different pre-soaking treatments in mango was carried out. Where Mango stones of Nekkare were obtained from one single lot from a processing unit and were used. The stones were pre-soaked viz., Control, $\mathrm{GA}_{3}$, Silicylic acid, Vermiwash and Cow urine of different concentrations. The different pre-soaking treatments of stones revealed that all the growth parameters were positively influenced and resulted in early germination. However, among the treatments the stones pre-treated with $\mathrm{GA}_{3} 500 \mathrm{ppm}$ for 10 minutes recorded significantly lower number of days taken for initiation and completion of germination, maximum germination percentage, root stock height, root stock diameter, number of leaves/root stock, highest graft success, graft survival per cent and germination index were significantly higher compared to control. Similarly, at 30,60 and 90 days of grafting $\mathrm{GA}_{3}-500 \mathrm{ppm}$ gave significant maximum graft height, graft diameter and more number of leaves per graft. Maximum graft success after three months of grafting was recorded with $\mathrm{GA}_{3}-500 \mathrm{ppm}(81.72 \%)$ followed by $\mathrm{GA}_{3}-250 \mathrm{ppm}(71.92 \%)$ and $\mathrm{Si} 6 \mathrm{ml} / \mathrm{l}$ $(67.09 \%)$. Significant maximum graft survivability was recorded with $\mathrm{GA}_{3}-500 \mathrm{ppm}$ $(76.11 \%)$ and $\mathrm{GA}_{3}-250 \mathrm{ppm}(72.29 \%)$ and less was recorded from cow urine at 50 per cent treatment.

\section{Introduction}

The mango (Mangifera indica L.) is the most important fruit of India. India is major mango producing country with an area of 2.297 million hectares with an annual production of 15.188 million tonnes and an average productivity of 6.6 tonnes per hectare Anon, (2011). The area under commercial varieties like alphonso is increasing rapidly owing to its great demand in international market. Even though the area under mango is increasing the pace of development is not appreciable. Limited availability of genuine planting material is the most important bottleneck in the expansion of area under mango. Since mango is highly cross-pollinated crop, as a result there is enormous variation in the seedlings raised from the fruits of single tree. The method of vegetative propagation such as grafting are thus introduced to obtain seedlings of true to type plants. Rootstocks are 
always seedling origin irrespective of zygotic/ nucellar nature. The viability of mango stones is only 12-50 per cent which is very low because stones are recalcitrant in nature (Singh 1960). In semi-arid regions the mango stones are available during the drier parts of the year (April- June) because of which the germination percentage and vigour is very low. Synchronization and rapid seed emergence are the commonly reported benefits of osmopriming and use og organics and gibberllic acid on the germination and seedling growth and are been successfully used for breaking the dormancy in seeds of numerous species and also accelerating the germination of non-dormant seeds.

The significant enhancement of germination was noticed in different pre-soaking treatments by Padma and Narayana Reddy (1998) and Venkat Rao, (2002) in mango. In dry zones of Karnataka, It has been observed that poor quality of rootstock is one of the majore causes for low success of softwood grafts even under conducive environment. It has been observed that rootstocks raised using potty mixture (red soil: sand: FYM in $1: 1: 1 \mathrm{v} / \mathrm{v}$ ) has poor roots thus making less vigorous and lanky growth. To overcome this use of silicon, $\mathrm{GA}_{3}$ and organics like vermiwash and cowurine at 50 per cent is used on the principles of introduction of number of saprophytes, growth promoting and bio control micro-organisms and their metabolites that aids in the nutrient release and its transport to the plants. Soaking of mango stones in $\mathrm{GA}_{3}$, Silicon and organics used have high beneficial effects on grafts and is known to improve the graft survival percentage and minimise the mortality rate. This necessitates raising the seedlings and rootstocks organically and inorganically to ensure higher graft take, better growth, more stem girth and development which is required for early grafting. The present investigation was conducted to study the germination and growth parameters by pre-soaking treatments with different organics, chemicals and growth regulators.

\section{Materials and Methods}

The present experiment was carried out during May 2012 to Jan 2013 at the Department of Fruit Science, Kittur Rani Channamma College of Horticulture, Arabhavi. A completely randomized design was adopted with three replications.

The experiment included eight treatments viz., $\mathrm{T}_{1}$ - Control (water soaking), $\mathrm{T}_{2}-\mathrm{GA}_{3}-250$ ppm, $\mathrm{T}_{3^{-}}$500ppm, $\mathrm{T}_{4^{-}}$Silica $2 \mathrm{ml} / 1, \mathrm{~T}_{5^{-}}$Silica $4 \mathrm{ml} / 1, \mathrm{~T}_{6}-$ Silica $6 \mathrm{ml} / 1, \mathrm{~T}_{7^{-}}$Vermiwash 50 per cent, $\mathrm{T}_{8^{-}}$Cow urine 50 per cent. Monoembryonic variety of 'Nekkare' mango stones obtained from single lot were used for the experiment. The stones were washed thoroughly and dipped in water and the floating stones were discarded and only those which settled in the bottom were selected and surface dried.

Required quantity of red soil, FYM and sand are taken and mixed in 1:1:1 proportion and the solution of vermiwash at 50 per cent and cowurine at 50 percent was prepared for the experiment. The stones were sown in polythene bags after soaking as per the treatments. The observations were recorded for days taken for initiation and completion of germination and oher morphological observations like root stock height, its diameter, number of leaves, height of the graft and Germination percentage and germination vigour index $(\mathrm{GVI})$ were computed using the formulae:

Germination percentage $=$

Number of stones germinated

x 100

Number of stones sown 


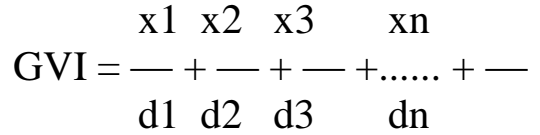

Where $\mathrm{x} 1, \mathrm{x} 2, \mathrm{x} 3$, xn were the number of stones germinated and $\mathrm{d} 1, \mathrm{~d} 2, \mathrm{~d} 3 \ldots \ldots \mathrm{dn}$ days taken for germination, respectively. The vigorously grown four month old rootstock in containers was selected and top growth was decapitated with sharp knife. Care was taken while selecting the scion material to match the girth of the stock. Necessary plant protection measures were taken to combat the pest problems as and when required. The observations were recorded daily for germination parameters, growth parameters, three months after grafting (MAG) for graft success and graft survival percentage and monthly interval for graft growth parameters. Statistical analysis of the data was done by following the Fisher's analysis of variance (ANOVA) technique given by Panse and Sukhatme (1967). The level of significance used ' $\mathrm{F}$ ' and' $\mathrm{t}$ ' tests was $\mathrm{P}=0.05$.

\section{Results and Discussion}

\section{Germination of stones pre-soaked}

Out of the eight soaking treatments used for germination of mango stones, there was significant difference in the germination and completion of germination of mango stones along with varied response on germination and growth. Control stones took longer period of 16.08 days for germination and 51.67 days for completion of germination, whereas, minimum time was observed from $\mathrm{GA}_{3}$ at 500 ppm treated stones of 11.41 days for germination and 33.91 days for completion of germination followed by Silicylic acid at $6 \mathrm{ml}$ per litre which recorded 14.24 days for stone germination which are statistically significant. Similarly, control stones took had 58.14 per cent germination while $\mathrm{GA}_{3}-500$ ppm increased the germination up to 72.25 per cent followed by $\mathrm{GA}_{3}-250 \mathrm{ppm}$ and vermiwash 50 per cent. Initiation of germination was also earlier compared to control (Table 1). The germination index ranged from 3.47 to 7.15 . The stones pre-soaked with $\mathrm{GA}_{3}-500 \mathrm{ppm}$ had shown significantly highest germination index (7.15) which was statistically on par with $\mathrm{Si}$ $6 \mathrm{ml}$ per litre (6.68), while stones pre-soaked with water recorded significantly lowest germination index (3.47). This could be due to that seedling emergence is primarily function of moisture available to seed and temperature effects (Kotowaski, 1996). The relative activity of treating the mango stones with chemicals before sowing to reduce the period taken for germination and to remove the obstructions in embryo growth had been reported in mango by Padma and Narayana Reddy (1990) and Shalini et al., (1999). This pre-soaking treatment would have effected and altered the enzymatic reaction involved in germination process. Thus, the enhanced enzymatic reactions along with suppression of inhibitors might have acted in the faster germination. The variation in germination in pre-soaking of stones may be due to the simulative effect of these chemicals on the stones as well as enhanced enzymatic process and suppression of inhibition along the synthesis of RNA, which might had resulted in higher germination. These results are in confirmation with the findings of Padma and Narayana Reddy (1998), and Reddy and Khan (2001). Consequently low vigour index and vigour of stock noticed in control due to low germination and slow seedling growth of the height were reported by Reddy and Khan (2001) in khirini seeds, Narayana Reddy (1993) in Aonla and Padma and Narayana Reddy (1998) in mango.

\section{Effect of pre-soaking treatments on vegetative parameters}

The osmopriming and growth regulators treatments had beneficial effects on mango 
rootstocks. There effects were significantly evident from increase in vegetative parameters viz., rootstock height, rootstock diameter number of leaves compared to control (Table 2 ). The influence of osmopriming, chemicals and growth regulators might have attributed in the beneficial effect of vegetative parameters. At 30 days after sowing in the growth response $\mathrm{GA}_{3} 500$ ppm exhibited significantly highest root stock height $(29.99 \mathrm{~cm})$ followed by $\mathrm{Si} 6 \mathrm{ml} / 1(24.90 \mathrm{~cm})$ and least recorded in vermiwash $(17.07 \mathrm{~cm})$. The rootstock diameter was significantly maximum in $\mathrm{GA}_{3}$ $500 \mathrm{ppm}$ and $\mathrm{Si}$ 6ml/1 $(6.29 \mathrm{~mm}$ and $6.04 \mathrm{~mm}$ respectively), while control showed minimum diameter of $4.21 \mathrm{~mm}$ at 30 days after sowing. Significantly more number of leaves were observed with $\mathrm{GA}_{3} 250 \mathrm{ppm}$ and $\mathrm{Si} 6 \mathrm{ml} / \mathrm{l}$ (6.71 and 6.29) where as minimum number of leaves were observed in control (5.38) (Table 2).

Similarly, at 60 DAS the growth response with $\mathrm{GA}_{3} 500$ ppm gave significantly highest rootstock height $(32.45 \mathrm{~cm}) \mathrm{GA}_{3} 250 \mathrm{ppm}$ followed by $\mathrm{Si} 6 \mathrm{ml} / 1(26.81 \mathrm{~cm}$ and $25.29 \mathrm{~cm})$ which were higher when compared with that of control $(19.32 \mathrm{~cm})$. The rootstock diameter was significantly maximum in $\mathrm{GA}_{3} 500 \mathrm{ppm}$, $\mathrm{GA}_{3} 250 \mathrm{ppm}$ and $\mathrm{Si} 6 \mathrm{ml} / 1(7.03 \mathrm{~mm}, 6.39 \mathrm{~mm}$ and $6.69 \mathrm{~mm}$ respectively), while silica $2 \mathrm{ml} / 1$ showed minimum diameter of $5.94 \mathrm{~mm}$ at 60 days after sowing. Significantly more number of leaves were observed with $\mathrm{GA}_{3} 250 \mathrm{ppm}$ and $\mathrm{GA}_{3} 500 \mathrm{ppm}$ (11.72, 10.48 and 9.98) where as minimum number of leaves were observed in control (9.18) (Table 2).

Silicon forms complexes with organic compounds in the cell wall of epidermal cells and helps in cell elongation and this property might of silicon would have helped in more root stock height.

During 90 days after sowing recorded significantly maximum rootstock height with
$\mathrm{GA}_{3} 250 \mathrm{ppm}$, Si 6ml/1 and Si 4ml/1 (44.26 $\mathrm{cm}, 29.74 \mathrm{~cm}$ and $31.75 \mathrm{~cm}$ respectively), where as minimum rootstock height was recorded in vermiwash 50 per cent $(25.43 \mathrm{~cm})$. The rootstock diameter was significantly maximum in $\mathrm{GA}_{3} 500 \mathrm{ppm}, \mathrm{GA}_{3}$ 250ppm and Si $6 \mathrm{ml} / 1$ (7.93mm, $7.14 \mathrm{~mm}$ and $7.03 \mathrm{~mm}$ respectively), while control showed minimum diameter of $5.95 \mathrm{~mm}$ at 90 days after sowing. Significantly more number of leaves were observed with $\mathrm{GA}_{3} 500$ ppm, GA 250 ppm and $\mathrm{Si} 6 \mathrm{ml} / \mathrm{l}(10.78,11.28$ and 11.13) where as minimum number of leaves were observed in vermiwash 50 per cent (5.73) (Table 2).

Similarly the influence of osmopriming, chemicals and growth regulators might have attributed in the beneficial effect of vegetative parameters. At 30 days after grafting in the growth response $\mathrm{GA}_{3} 500$ ppm exhibited significant highest graft height $(30.09 \mathrm{~cm})$ followed by $\mathrm{GA}_{3} 250 \mathrm{ppm}(24.45 \mathrm{~cm})$ and lesser in control. The graft diameter was significantly maximum in $\mathrm{GA}_{3} 500 \mathrm{ppm}, \mathrm{GA}_{3}$ $250 \mathrm{ppm}$ and $\mathrm{Si} 6 \mathrm{ml} / \mathrm{lt}$. (7.78mm, 5.45mm and $6.18 \mathrm{~mm}$ respectively), while vermiwash showed minimum diameter of $5.45 \mathrm{~mm}$ at 30 days after grafting. Significantly more number of leaves were observed with $\mathrm{GA}_{3} 500 \mathrm{ppm}$ (7.93), $\mathrm{GA}_{3} 250 \mathrm{ppm}$ and $\mathrm{Si} 6 \mathrm{ml} / \mathrm{lt}$. (6.71 and 6.29) where as minimum number of leaves were observed in vermiwash 50 per cent (5.45) at 30 days after grafting (Table 3 ).

Similarly, at 60 DAG the growth response with $\mathrm{GA}_{3} 500$ ppm gave significantly highest graft height $(32.55 \mathrm{~cm})$ followed by $\mathrm{GA}_{3} 250$ ppm and $\mathrm{Si} 6 \mathrm{ml} / \mathrm{lit}(28.54 \mathrm{~cm}$ and $21.66 \mathrm{~cm})$ which were higher when compared with that of control $(19.70 \mathrm{~cm})$. The graft diameter was significantly maximum in $\mathrm{GA}_{3} 500 \mathrm{ppm}, \mathrm{GA}_{3}$ $250 \mathrm{ppm}$ and $\mathrm{Si} 6 \mathrm{ml} / \mathrm{lt}$ was $7.51 \mathrm{~mm}, 6.70 \mathrm{~mm}$ and $6.42 \mathrm{~mm}$ respectively), while vermiwash showed minimum diameter of $5.88 \mathrm{~mm}$ at 60 days after grafting. Significantly more number of leaves were observed with $\mathrm{GA}_{3} 500$ ppm 
(8.11), $\mathrm{GA}_{3} 250 \mathrm{ppm}$ and control (8.89 and 7.08) where as minimum number of leaves were observed in vermiwash 50 per cent (5.88) at 60 days after grafting (Table 3).

During 90 days after grafting significant maximum graft height was exhibited with $\mathrm{GA}_{3}$ $500 \mathrm{ppm}, \mathrm{GA}_{3} 250 \mathrm{ppm}$ and $\mathrm{Si} 6 \mathrm{ml} / \mathrm{l}$ (34.45 $\mathrm{cm}, 31.82 \mathrm{~cm}$ and $23.69 \mathrm{~cm}$ respectively). The graft diameter was significantly maximum in
$\mathrm{GA}_{3} 500 \mathrm{ppm}, \mathrm{GA}_{3} 250 \mathrm{ppm}$ and $\mathrm{Si} 6 \mathrm{ml} / \mathrm{l}$ $(8.52 \mathrm{~mm}, \quad 8.75 \mathrm{~mm}$ and $6.81 \mathrm{~mm}$ respectively), while vermiwash showed minimum diameter of $5.73 \mathrm{~mm}$ at 90 days after grafting. The maximum number of leaves were observed with $\mathrm{GA}_{3} 500 \mathrm{ppm}$ (9.49), $\mathrm{GA}_{3}$ $250 \mathrm{ppm}$ and $\mathrm{Si} 6 \mathrm{ml} / \mathrm{lt}$ (8.87 and 8.07) where as minimum number of leaves were observed in vermiwash 50 per cent (5.73) at 90 days after grafting (Table 3 ).

Table.1 Effect of chemicals and GA3 pre-soaking treatments on germination characters of mango stones

\begin{tabular}{|c|c|c|c|c|}
\hline \multirow[t]{2}{*}{ Treatment } & \multicolumn{2}{|c|}{$\begin{array}{l}\text { Number of days taken for } \\
\text { germination }\end{array}$} & \multirow[t]{2}{*}{$\begin{array}{l}\text { Germination } \\
\text { per cent }\end{array}$} & \multirow[t]{2}{*}{$\begin{array}{l}\text { Germination } \\
\text { Index }\end{array}$} \\
\hline & Initiation & Completion & & \\
\hline T1-Control & 16.08 & 45.59 & 51.67 & 3.47 \\
\hline T2-GA $250 p p m$ & 12.37 & 34.86 & 65.77 & 6.68 \\
\hline T3-GA $3500 p p m$ & 11.41 & 33.91 & 72.25 & 7.15 \\
\hline T4-Si 2ml/l & 14.51 & 39.41 & 50.47 & 5.19 \\
\hline T5-Si 4ml/l & 14.67 & 40.18 & 52.41 & 6.06 \\
\hline T6-Si $6 \mathrm{ml} / \mathrm{l}$ & 14.24 & 42.22 & 55.56 & 5.19 \\
\hline T7-Vermiwash 50 per cent & 15.43 & 41.07 & 61.73 & 5.64 \\
\hline T8-Cowurine 50 per cent & 16.12 & 50.91 & 58.14 & 3.68 \\
\hline S.Em \pm & 0.41 & 1.16 & 1.46 & 0.32 \\
\hline C.D@5\% & 1.23 & 3.49 & 4.40 & 0.97 \\
\hline
\end{tabular}

Table.2 Effect or pre-sowing treatments on rootstock height, diameter and number of leaves per rootstock of mango at different stages of growth

\begin{tabular}{|c|c|c|c|c|c|c|c|c|c|}
\hline \multirow[t]{2}{*}{ Treatments } & \multicolumn{3}{|c|}{ Rootstock height (cm) } & \multicolumn{3}{|c|}{$\begin{array}{l}\text { Rootstock } \\
(\mathbf{m m})\end{array}$} & \multicolumn{3}{|c|}{ Number of leaves } \\
\hline & $\begin{array}{l}30 \\
\text { DAS }\end{array}$ & $\begin{array}{l}60 \\
\text { DAS }\end{array}$ & $\begin{array}{l}90 \\
\text { DAS }\end{array}$ & $\begin{array}{l}30 \\
\text { DAS }\end{array}$ & $\begin{array}{l}60 \\
\text { DAS }\end{array}$ & $\begin{array}{l}90 \\
\text { DAS }\end{array}$ & $\begin{array}{l}30 \\
\text { DAS }\end{array}$ & $\begin{array}{l}60 \\
\text { DAS }\end{array}$ & 90 DAS \\
\hline T1-Control & 18.76 & 19.32 & 30.26 & 4.21 & 5.80 & 5.96 & 5.38 & 09.18 & 09.07 \\
\hline T2-GA $3250 p p m$ & 23.45 & 26.81 & 29.74 & 5.13 & 6.39 & 7.14 & 6.71 & 11.72 & 11.28 \\
\hline T3-GA 3 500ppm & 29.99 & 32.45 & 44.26 & 6.29 & 7.03 & 7.93 & 6.26 & 10.48 & 10.70 \\
\hline T4-Si2ml/l & 21.91 & 22.56 & 30.66 & 4.38 & 5.19 & 5.94 & 4.99 & 09.29 & 10.40 \\
\hline T5-Si4ml/l & 19.45 & 20.37 & 31.41 & 5.18 & 5.40 & 6.10 & 5.48 & 09.32 & 10.96 \\
\hline T6-Si6ml/l & 24.90 & 25.29 & 31.75 & 6.04 & 6.69 & 7.03 & 6.29 & 09.98 & 11.13 \\
\hline T7-Vermiwash 50 per cent & 17.07 & 19.71 & 25.43 & 5.09 & 5.58 & 6.14 & 6.20 & 08.78 & 09.24 \\
\hline T8- cowurine 50 per cent & 18.69 & 20.80 & 29.86 & 5.26 & 5.63 & 6.29 & 6.00 & 07.79 & 09.45 \\
\hline SEm \pm & 0.68 & 0.84 & 1.47 & 0.27 & 0.27 & 0.28 & 0.11 & 0.17 & 0.27 \\
\hline CD@5\% & 2.03 & 2.54 & 4.42 & 0.81 & 0.83 & 0.85 & 0.35 & 0.53 & 0.83 \\
\hline
\end{tabular}


Table.3 Effect or pre-sowing treatments on graft height, diameter and number of leaves per graft of mango at different stages of growth

\begin{tabular}{|c|c|c|c|c|c|c|c|c|c|}
\hline \multirow[t]{2}{*}{ Treatments } & \multicolumn{3}{|c|}{ Graft height $(\mathbf{c m})$} & \multicolumn{3}{|c|}{ Graft diameter (mm) } & \multicolumn{3}{|c|}{ Number of leaves/graft } \\
\hline & $\begin{array}{l}30 \\
\text { DAG }\end{array}$ & $\begin{array}{l}60 \\
\text { DAG }\end{array}$ & $\begin{array}{l}90 \\
\text { DAG }\end{array}$ & $\begin{array}{l}30 \\
\text { DAG }\end{array}$ & $\begin{array}{l}60 \\
\text { DAG }\end{array}$ & $\begin{array}{l}90 \\
\text { DAG }\end{array}$ & $\begin{array}{l}30 \\
\text { DAG }\end{array}$ & $\begin{array}{l}60 \\
\text { DAG }\end{array}$ & $90 \mathrm{DAG}$ \\
\hline T1-Control & 19.76 & 20.70 & 24.32 & 5.13 & 5.85 & 6.32 & 6.87 & 7.87 & 7.87 \\
\hline T2-GA 3 250ppm & 24.45 & 28.54 & 31.82 & 5.45 & 6.70 & 8.75 & 6.86 & 8.89 & 8.87 \\
\hline T3-GA 3 500ppm & 30.09 & 32.55 & 34.45 & 7.78 & 7.51 & 8.52 & 7.93 & 8.11 & 9.49 \\
\hline $\mathrm{T} 4-\mathrm{Si} 2 \mathrm{ml} / \mathrm{l}$ & 17.77 & 19.63 & 20.24 & 4.53 & 4.97 & 5.80 & 3.51 & 4.20 & 5.80 \\
\hline T5-Si4ml/l & 18.96 & 19.42 & 19.67 & 5.54 & 5.81 & 6.61 & 4.06 & 4.81 & 5.29 \\
\hline T6-Si6ml/l & 19.62 & 21.66 & 23.69 & 6.18 & 6.42 & 6.81 & 6.70 & 7.08 & 8.07 \\
\hline $\begin{array}{l}\text { T7-Vermiwash } \\
50 \text { per cent }\end{array}$ & 18.74 & 19.11 & 20.03 & 5.26 & 5.43 & 6.82 & 4.54 & 5.18 & 5.73 \\
\hline $\begin{array}{l}\text { T8- cowurine } 50 \\
\text { per cent }\end{array}$ & 17.00 & 17.83 & 17.45 & 5.25 & 5.08 & 5.74 & 4.50 & 4.67 & 5.81 \\
\hline SEm \pm & 0.16 & 1.06 & 1.07 & 0.09 & 0.07 & 0.11 & 0.62 & 0.54 & 0.68 \\
\hline CD@5\% & 0.48 & 3.18 & 3.21 & 0.28 & 0.22 & 0.31 & 1.84 & 1.62 & 2.04 \\
\hline
\end{tabular}

Table.4 Effect or pre-sowing treatments on graft success and graft survivability (percentage) of mango at different stages of growth

\begin{tabular}{|c|c|c|}
\hline \multirow[t]{2}{*}{ Treatments } & Graft Success (\%) & Graft Survivability (\%) \\
\hline & $3 \mathrm{MAG}$ & $6 \mathrm{MAG}$ \\
\hline $\mathbf{T}_{1}-$ Control & 63.18 & 67.49 \\
\hline$T_{2}-G_{3} 250 \mathrm{ppm}$ & 72.92 & 72.29 \\
\hline$T_{3}-G^{-} A_{3} 500 \mathrm{ppm}$ & 80.72 & 76.13 \\
\hline $\mathrm{T}_{4} \mathrm{Si} 2 \mathrm{ml} / \mathrm{l}$ & 56.52 & 53.03 \\
\hline $\mathrm{T}_{5}-\mathrm{Si} 4 \mathrm{ml} / \mathrm{l}$ & 58.10 & 65.11 \\
\hline $\mathrm{T}_{6}-\mathrm{Si} 6 \mathrm{ml} / \mathrm{l}$ & 65.54 & 66.59 \\
\hline$T_{7}-$ vermiwash $50 \%$ & 53.32 & 60.96 \\
\hline $\mathbf{T}_{8-}$ cow urine $50 \%$ & 50.18 & 59.93 \\
\hline SEm \pm & 1.89 & 2.86 \\
\hline CD@ $9 \%$ & 5.68 & 8.59 \\
\hline
\end{tabular}

The higher vegetative parameters and rootstock growth observed in present investigation can be attributed to effect presowing treatments with $\mathrm{GA}_{3}$, silica and organics which is known to release the substances to enhance the growth stimulating hormones. $\mathrm{GA}_{3}$ on simulation triggers hydrolytic and oxidative enzymes and helps almost exclusively in stem elongation properties and is done by inducing cell loosening, by increased solute concentration by increased cell wall exstensibility, stimulating the wall synthesis, reducing the rigidity of cell wall by increasing cell division leading to more growth. The indirect effect of $\mathrm{GA}_{3}$ on stem elongation is by increasing the 
synthesis of IAA (Leopold and Kriedemann, 1983). Vermiwash might have good results because it contains phosphate sulphates and chlorides of potassium, sodium and sulphur and ammonia are also found in small quantities. All these salts being in soluble form can diffuse into the plant system through stomatal openings which increases in size as reported by Karuna et al., (1990). The increase in seedling height and girth by application of gibberllic acid and potassium nitrate was also reported by earlier workers, Padma and Narayana Reddy (1998), Shalini et al., (1999) in mango and Reddy and Khan (2000) in Khirini. Hence, it is clear that the pre-soaking treatments has increased the vegetative growth parameters compared to control.

\section{Effect of pre-soaking treatments on graft- take}

There were significant differences observed among the different chemicals and growth regulator treatment on graft success and growth parameters. Maximum graft success was noticed in $\mathrm{GA}_{3}$ 500ppm $(80.72 \%)$ followed by $\mathrm{GA}_{3}$ at $250 \mathrm{ppm}(72.92 \%)$ and $\mathrm{Si}$ $6 \mathrm{ml} / 1$ (65.54\%). Significantly least graft success was noticed in cowurine 50 per cent $(57.97 \%)$. Similar trend was also noticed for graft survivability at six months after grafting (Table 4) significant maximum graft survivability was got from $\mathrm{GA}_{3} 500 \mathrm{ppm}$ $(76.13 \%)$ followed with $\mathrm{GA}_{3}$ at $250 \mathrm{ppm}$ $(72.29 \%)$ and $\mathrm{Si} 6 \mathrm{ml} / \mathrm{l}(66.59 \%)$ and less in cowurine at 50 percent $(61.76 \%)$ treatment. The influence of weather parameters like humidity and temperature on grafting and graft survival has been observed by (Patel and Amin, 1981). In their experiment they found that temperature range of 23.15 and $25.87{ }^{\circ} \mathrm{C}$ was the most favourable for success. Same reason may lead to higher success in the present investigation also. Pre-soaking treatments were found to be significant at all stages of growth with respect to graft height and number of leaves. Probably due to better growth of grafts and weather condition like temperature and humidity, this played important role in growth of grafts. This might be related to vigorous growth of grafts induced by simulative organs and also influenced by maximum number of maximum number of leaves. Similar, results were observed by (Sappandy, 2005) in wood apple and (Devechandra, 2006) in jamun. The higher graft-take observed in the present investigation may be attributed to the better growth of rootstock before grafting operation. It is clear from this experiment that the osmopriming treatments with chemicals and growth regulators increased the graft success, survivability and graft growth parameters compared to control.

\section{References}

Anonymous (2011). Indian Horticulture Data Base, National Horticultural Board, Gurgaon, India, pp.99. www.nhb.gov. in.

Devechandra, D (2006). Synergetic effect of AM Fungi in combination with bioformulation on germination: grafttake, growth and yield of jamun,. M.Sc. (Hort.) Thesis, Univ. Agric. Sci., Dharward (India).

Karuna, M. Doddamani and Katti C.K. (1990). Influence of organic on crinkle red variety of Anthurium Lind. Crop Res, 17(2): 253-257.

Korbragade, H.M. Patil, B.N. Patil S.P. and Belorkar P.V. (1999). Performance of mango rootstocks under nursery conditions. J. Soils and Crops, 9(2):244-246.

Leopold and Krieddemann E.T. (1983). Plant growth and development. Tata macgrow hill Pub. Co. Ltd. New Delhi.

Narayana Reddy (1998). Effect of pre- 
soaking treatment of stones of Aonla germination. Acta. Hort., 231.

Natarajan, K. (2002). Panchagavya- A Manual. Other India Press Maousa. Goa, pp.33

Padma M. and.Reddy N (1995). Influence of age of rootstock on epicotyls grafttake and growth in mango. South Indian Hort, 45:151-153.

Panse, V.G. and Sukhatme, P.V (1967). Statistical methods for Agricultural Workers. Indian Council of Agricultural Research, New Delhi, pp.152-161.

Patel B.M. and Amin R.S. (1981). Investigation into the best period for softwood grafting on mangoes in-situ. South Indian Hort., 29:90-93.

Pathak, R.K. and Ram R.A. (2004).Manual on Vedic Krishi, Central Institute For Subtropical Horticulture, Rehmankhera, Luknow, pp.1-38.

.Ram S (1997). Propagation. In: The Mango Botany, Production and Uses. Ed. Litz, R.E., CAB International, p. 367.

Reddy, Y. T. N and Khan, M. M. (2001). Effect of osmopriming on germination, seedling growth and vigour of Khirini (Mimusza hexandra) seeds. Seed research. 29(1): 24-27.
Reddy, C. V and Melanta, K. R. (1988). Effect of age of rootstock on the success of softwood grafting of mango in containers and insitu. South Indian Hort., 36.143-145.

Santosh (2004). Enhancement of germination, growth, graft-take and stress tolerance of mango rootstocks using bioformulations. M.Sc. (Hort.) Thesis, Univ. Agric. Sci., Dharwad (India).

Sappandi, S. (2005). Survey, evaluation and softwood grafting of wood apple (Feronia limonia L.) genotypes. M.Sc. (Hort.) Thesis, Univ. Agric. Sci. Dharwad.

Shalini, P., Bagde. T.R. and Bharati, B. (1999). Growth of mango (Mangifera indica L.) Seedlings as influenced by stone treatment. J. Soils and Crops, 9(2): 227-230.

Singh, N.P and Srivastva, R.P (1979). Studies on various factors involved in softwood grafting in mango. Prog. Hort., 4: 117-120.

Venkatarao and Reddy, Y.T.N. (2002). Effect of osmopriming on germination seedling growth and vigour of mango stones. The Karnataka J. Hort., 1 (4): 29-35.

\section{How to cite this article:}

Vidya, A., Swamy, G.S.K. and Praveenakumar, R. 2018. Influence of Salicylic Acid, Growth Regulators and Organics on Germination and Graft Take on Mango (Mangifera indica L.) Stones. Int.J.Curr.Microbiol.App.Sci. 7(08): 916-923. doi: https://doi.org/10.20546/ijcmas.2018.708.104 